\title{
CHAPTER 44 \\ ARTIFICIAL BEACH BUILDING ON THE CROISETTE WATERFRONT AT CANNES
}

\author{
LOUIS TOURMEN \\ Engineer, Sogréah \\ Grenoble
}

In view of the persistent increase in traffic density on the Crolsette and the restrictions caused by a one-way system which had to be introduced, the Cannes municipality decided to ease the situation by widening the road to handle two-way traffic.

Numerous schemes for widening the road on the seaward! side were proposed but none were satisfactory for the resulting gains were minimal, and the beach, which is at present very narrow and even non-existent at certain places (see fig. 2 ), would have suffered accordingly. Consulted on this problem, sogreah decided to examine the possibility of rebuilding the beach to start with, to be followed by the construction of a new, wide promenade, the net effect being a wider beach than the existing one. Since the beach could not be expected to extend naturally, this involved the construction of a completely man-made beach. This artiflcial beach bulling is extremely attractive from a technical point of view, since it presents no snags but it was nevertheless considered advisable to verify that this method could be applied to the croisette beach.

The Cannes Council Technical Department commissioned Sogréah to do a study, the aim of which was to discover whether the artificial beach would be sufficiently stable without extensive maintenance.

This report is a record of these studies and the practical achievements they made possible. 


\title{
COASTAL ENGINEERING
}
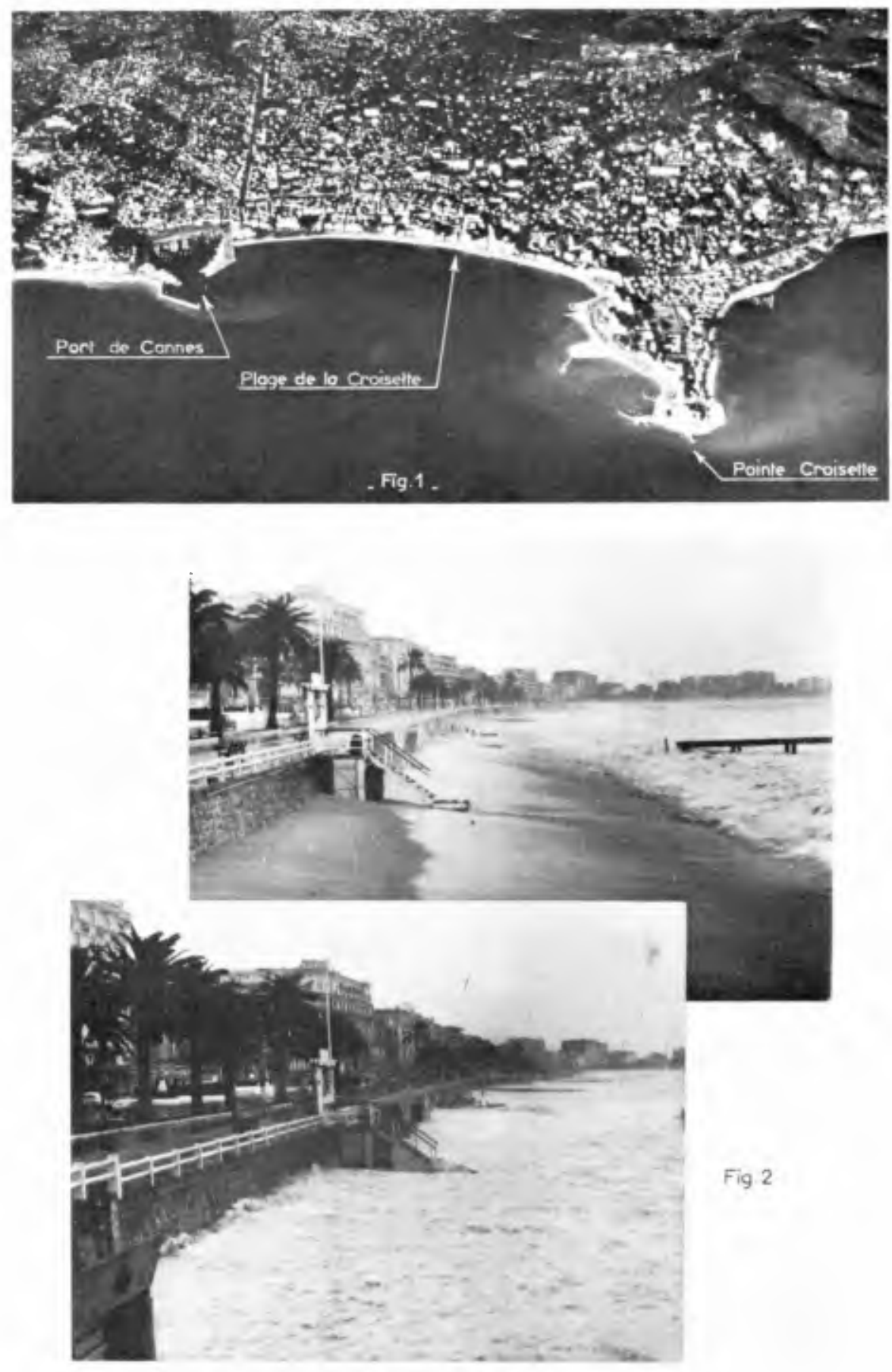

La playa antes del acandicianamienta,

La plage avant aménagement. durante un remporal

The beach before improvement, par gros temps

\author{
in heavy wealher
}




\title{
ARTIFICIAL BEACH BUILDING ON THE CROISETTE WATERFRONT AT CANNES
}

\author{
STABIIITY OF THE SHORE A'LONG THE CANNES ROADSTEAD
}

The shore of the Cannes roadstead stretches between two protecting arms which make it a separate entity, cut off from the rest of the adjolning coastline. These two limits are as follows (see fig. 1 ):

\section{1) Eastwards}

The Crolsette point, presumably underlain by rock, of which the Iles de Lérins may be considered to be a prolongation seawards.

\section{2) Westwards}

The port, whose west jetty springs from the saint-Plerre rock and whose east jetty protects the fill on which the Casino is built.

For more than a century this shore has been undergoing profound changes. A plan dating from 1823 shows that there was no man-made interference with lts natural development at this time. It seems likely that quantities of sand were brought into the bay to the east of the saintPlerre rock, on the present site of the harbour. Sedimentation in varying degrees also took place ow ing to the influence of numerous small streams spread out along the coast, emptying a small catchment area down their gul11es.

Subsequent and numerous development schemes have seriously cut down the natural sedimentation of the area.

In the first place the harbour protection works form an impenetrable barrier to material coming from the beaches of the Gulf of La Napoule. Moreover, the quantity of such material has been arastically reduced by the commercial exploitation of the river siagne sand deposits, to the west of Cannes.

In the same way the sedimentation due to the gullies has been largely stopped by works carried out in their upper sections.

On can therefore state that natural sedimentation in the cannes roadstead, and settling one the beach, is at the present moment minimal.

At the same time various kinds of artificial deposits were brought on to this beach, mainly in the form of waste products from constructional work. When the foundations were being dug for the big hotels the resulting rubble etc. was dumped directly on the beach. This form of tipping was banned in 1926 and since then no artificlal deposits have been placed on the Crolsette.

The above survey shows that the Crolsette at the present moment recelves no form of deposits, whether natural or artificlal. This is a first plece of evidence as to 1 ts being in a state of stable equilibrium. 


\section{COASTAL ENGINEERING}
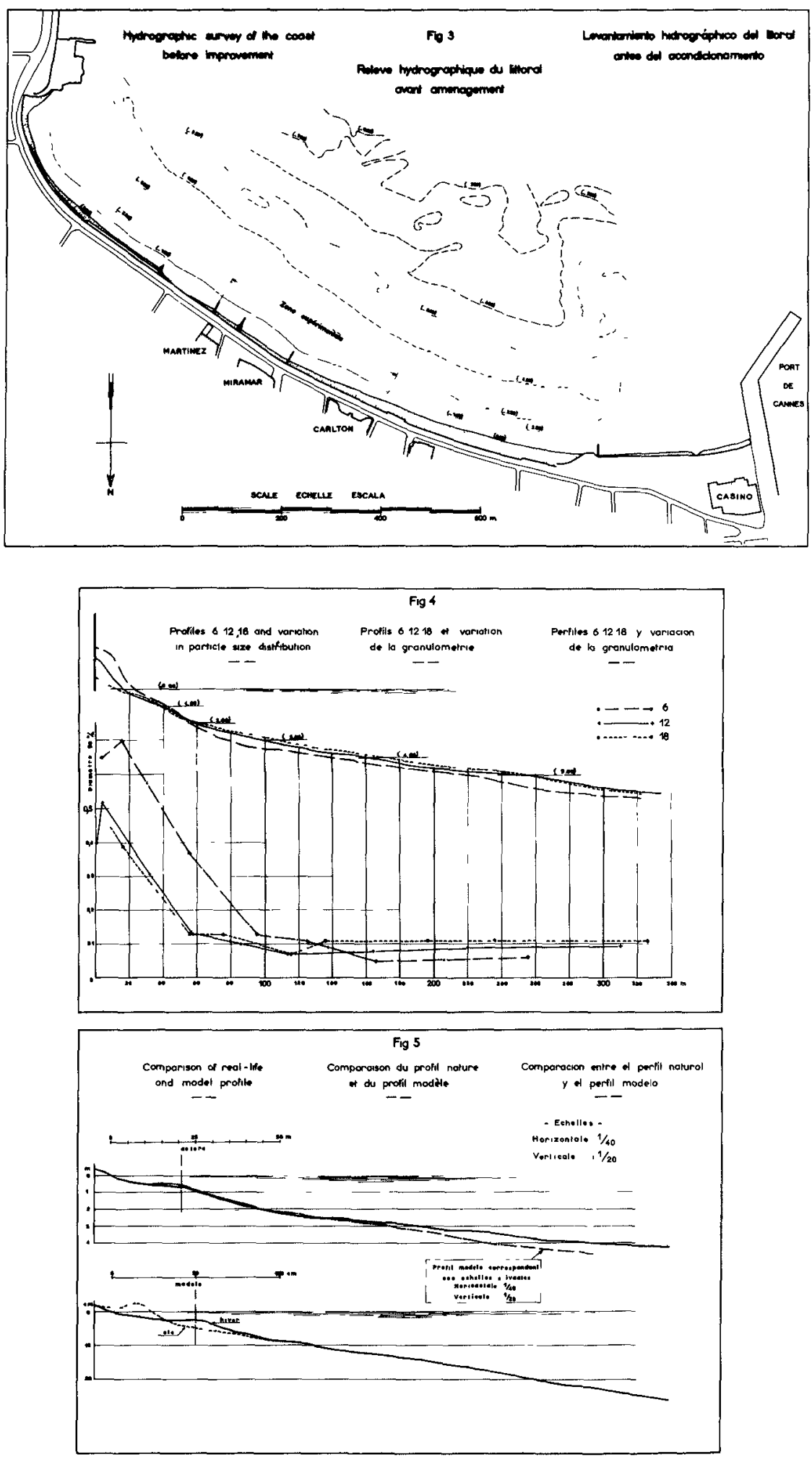


\section{ARTIFICIAL BEACH BUILDING ON THE CROISETTE WATERFRONT AT CANNES}

Further evidence in support of this statement is provided by a comparison between the French Navy Hydrographical Service survey in 1897 and that carried out by Sogréah in 1960. This reveals that only very limited development has taken place, with no large-scale movement of materials. It is probable, moreover, that what little change has taken place has been due to the building of the palais des sports, at the eastern end of the roadstead, since it is in this area that development is most obvious.

Other factors also tend to confirm this stability. The sea-bed, for example, is covered by vegetation down to a depth of $4 \mathrm{~m}$, which is always a certain pointer to stability. Finally, the water-tight jetties on the beach do not reveal any noteworthy deposits in any one direction, and this denotes the absence of a prevailing movement of sand. All these factors tend to demonstrate that the beach is in fact in a state of stable equilibrium, generally speaking, at least over a fifty-year period. This conclusion is the prerequisite for successful beach building, as artificial accretion is able to last only on a beach in a state of dynamic equilibrium.

\section{CHARACTERISTICS OF THE CROISETTE BEACH}

Examination reveals that the profiles chosen along the whole length of the beach resemble each other fairly closely. This fact is seen at once by looking at a sea chart of the roadstead, the contours of which are parallel and show a regular concave shape. The typical profile at the basis of our study is extremely representative. It is $n^{\circ} 12$, $f i g$. 3 and was taken from midway along the shore. It was used for all the general studies. This profile, is to be found among others, in fig. 4 drawn with a 5 to 1 distortion.

The profile from the beach down to the $2 \mathrm{~m}$ mark has a gradient of about $5 \%$. Afterwards the slope flattens out to between 1 and $2 \%$. This second section goes as far as the vegetation. Simultaneously with the plotting of profiles, sediment samples were taken from the sea-bed at the same points. Particle-size analys is showed a certain correlation between levels and gradients on the one hand, and the $50 \%$ sample diameter on the other.

Fig. 4 gives this correlation for three profiles taken at random along the beach. At this point it is worth noting that for a $5 \%$ gradient a $50 \%$ particle diameter represents approx. 0.2 to $0.3 \mathrm{~mm}$ whereas for a 1 to $2 \%$ gradient the figure is from 0.05 to $0.1 \mathrm{~mm}$. These granulometric studies were of great help in determining choice of material for beach building.

Qualitatively speaking, the range of material found on the Croisette beach is very wide and of fairly recent date, which is after all normal since the original beach was composed of a wide range of materials tipped in recent times. 


\section{COASTAL ENGINEERING}

Also worth noting is a characteristic change in profile of the upper section of the beach during the December to July perlod, caused by seasonal variation in the standard profile.

\section{PRELIMINARY STUDIES OF POSSIBLE WAYS OF DEVELOPING THE BEACH}

The problem was to build up the profile, basically similar to those in fig. 4, with sand, so as to create a new, stable beach, thirty metres or so in front of the previous one. The Cannes Municipal Councll Technical Department accepted an increase of 20 to 30 metres as sufficient.

\section{NATURE OF SAND TO BE USED}

Rlght from the start an over-riding consideration was the particlesize of the sand avallable for beach bullding.

The particle-size of the added sand had first of all to be compared with that of the existing beach, to determine whether the work would be successful or not and to reject any unsultable material.

Generally speaking, on a given beach, the added sand to be really stable, should be much coarser than that already in position. Proof of this is to found on the crolsette beach, which is really an artificlal beach composed of widely-varying materials but where nevertheless the largest particles have remalned in position at the head of the beach (see fig. 4 ).

If beach building is carried on by depositıng sand of a finer grade on top of the existing beach there is a strong chance that it will progres sively slip downhlll into the sea. It is thus lmpossible (without taking special precautions) to transform a pebble beach into a stable sandy beach merely by dumping material on the head of the beach. One may attempt to hold this sand in place by artificial means, but this always increases the cost of the undertaking very considerably.

The above remarks are practically always valid but especially so in areas where tides are very weak and waves are mostly the result of local winds, i.e. as at Cannes. The erosion produced by such waves is far greater than that of swell coming in from far distances; on account of the absence of tides, the bed materials are more evenly sorted at least in relatively shallow waters.

Simultaneously with our studies, the Cannes Council Technical Department were surveying for possible sources of good quality sand, preferably in the region. Certain deposits were in fact found on the sea-bed near the Crolsette point and the Lérins ls lands but both quantity and quality were deficient. Analysis revealed up to $40 \%$ of crushed shells in the samples, whlch is much to high, owing to the low density of crushed shells. 


\section{ARTIFICIAL BEACH BUILDING ON THE CROISETTE WATERFRONT AT CANNES}

An attempt was therefore made to find other deposits and at the time of these preliminary studies it seemed that medium quality sand of rather fine grade would have to be accepted.

The study continued based on these assumptions; the added deposits were assumed to have the same granulometric characteristics as the existing sand on the beach. The a priorl solution therefore seemed to favour an underground retaining barrier whlch, although perhaps not essential, would nevertheless improve the stablity of the added material.

The problem was reduced to the study of the stability of the proposed beach extension based on a profile using the same particle-size as the existing ones. The simplification of the problem to these terms made 1t much more accessible to experimental study.

After the conclusion of the preliminary studies, 1t should be noted that the Cannes Council Technical Department managed to find a deposit of excellent sand, with the required granulometric qualities. This discovery had a most beneficial effect on subsequent operations, and will be commented on subsequentiy.

\section{EXPERIMENTAL SCALE-MODEL STUDIES}

A few tests were carried out in a glass-walled flume in order to find out what would happen during beach building.

This flume was able to produce waves elther by the classical wavepaddle method or by a stream of alr blown across the surface, the speed of which could be varied.

In the above flume the beach was reconstructed by bullding up the head of the foreshore. The wave amplitude was set at an average value corresponding to an air-speed of 4 metres per sec. The material used was ground pumice of density 1.4 .

We must make it quite clear that this model was never intended to be an exact reproduction of the actual phenomenon. It was merely an analogy which helped to clarify the problems but could not provide solutions.

The beach reconstructed in the flume gradually settled down and when this process was practically completed, the resulting profile was compared with the typical profile of the Cannes beach. This comparison was satisfactory, provided that the hor izontal scale and scale distortion were properly selected.

Flg. 5 shows the experimental profile superposed on the typical profile drawn to a horizontal scale of $1: 40$ and a vertical scale of $1: 20$, i.e. a distorsion of 2 . Varlous tests were carrled out on this profile to study the artificlal bullding-up, of the beach. The tests fall into three groups :-

1) Study of the behaviour of material ldentical to the basic profile material, dumped on the beach and subject to wave action. 


\section{COASTAL ENGINEERING}

2) With the same lay-out, the effect of a toe-mound placed about a hundred metres from the beach was studied.

3) In the final group a study was made of the influence of dumping methods on the final equilibrium of the beach.

Without going into detail we shall glve the results whibh we were able to obtain. The first two groups of tests in the wave flume revealed that artificial beach building was possible but would involve constant maintenance, since when not protected by a toe-mound the beach offers low resistance to wave action in storms and the extension obtained is reduced every winter owing to loss of material swept out to sea during heavy weather. These losses would have to be replaced from time to time. These tests are only valid for material identical to that constituting the original beach.

On the other hand, the extension can be protected successfully even during very heavy seas by the construction of a water-tight sand toe-mound about a hundred metres from the shore.

The third group of tests demonstrated, at least experimentally, that dumping methods had no effect on the final result. We have nevertheless recommended that the actual building-up of the beach be done as progressively as possible.

\section{CONCLUSIONS FROM THE PRELIMTNARY STUDIES}

The conclusions of the above preliminary studies are that beach building with materlals of the same particle-size as on the original beach was not an economic proposition without the addition of a toe-mound to check loss of material in the sea, unless the necessity of periodic replacement of material were accepted.

With a toe-mound an estimated $25 \mathrm{~m}$ of beach would be gained at a cost of $200 \mathrm{cu} . \mathrm{m}$. per metre run of shore.

\section{EXPERIMENTAL BEACH BUILDING ON SITE}

The relatively favourable conclusions of the preliminary studies and the discovery of deposits of sand of coarser grade than that previously available prompted the Technical Department of Cannes Council to consent to the building of an experimental section on the beach of the Croisette.

\section{NATURE OF SAND USED}

The sand finally chosen came from Fréjus, $40 \mathrm{~km}$ from Cannes. Its particle-size and general appearance were eminently suitable. 


\title{
ARTIFICIAL BEACH BUILDING ON THE CROISETTE WATERFRONT AT CANNES
}

\author{
Transport from the source was carried out by heavy lorries.
}

Fı\&. 6 gives the average granulometric curve of the sand chosen and also the granulometric curves corresponding to samples taken at varlous depths on profile 12, before starting the development work. It is thus obvious that the added sand was much coarser than the or iginal at all points along the profile.

The quality of the sand available for the tests made it possible to decrease the amount used and the final figure was about $100 \mathrm{cu} . \mathrm{m}$ per metre run.

\section{EXPERIMENTAL SITE}

Fig. 3 gives the exact site of the experimental area, which extended over a distance of $330 \mathrm{~m}$ and included profile 12 , described below.

The limits of the area were marked by dikes to prevent lateral spreading of the sand. An experimental toe-mound of sand-filled nylon sacks was placed along a distance of about $80 \mathrm{~m}$ situated in the centre of the area, at about $100 \mathrm{~m}$ from the low water mark. Given the grade of sand used it is questionable whether such a mound was really necessary. The experimental nature of the project seemed to recommend one but the subsequent course of events showed that it was superfluous.

The test revealed some loss of sand at the edges of the area, except in the case of the eastern dike, which was a masonry construction.

This loss of sand modifies the information provided by the experiments only by affecting the results obtained in a conservative sense.

\section{SAND DUMPING}

Total mount dumped : $29,550 \mathrm{cu.m}$, at a daily rate of $850 \mathrm{cu.m}$.

It is worth noting that the above figures for daily and total amounts were measured in lorry-loads. We were interested in finding out, by means of a comparison with profiles constructed before and after dumping, the actual volume of sand mesured in situ. This comparison would seem to reveal a certain ratio assumed by us as constant, between the amount glven by measuring lorry-loads and that given by comparing bed surveys.

\section{This ratio is in the region of $2 / 3$.}

From now on volumes measured by the lorry-load method will be marked by an asterisk. The average amount placed along the $330 \mathrm{~m}$ of the experimen. tal area was :

$$
\frac{29,550^{*} \mathrm{cum}}{330 \mathrm{~m}} \not \neq=50^{*} \text { cu m per metre run }
$$


COASTAL ENGINEERING
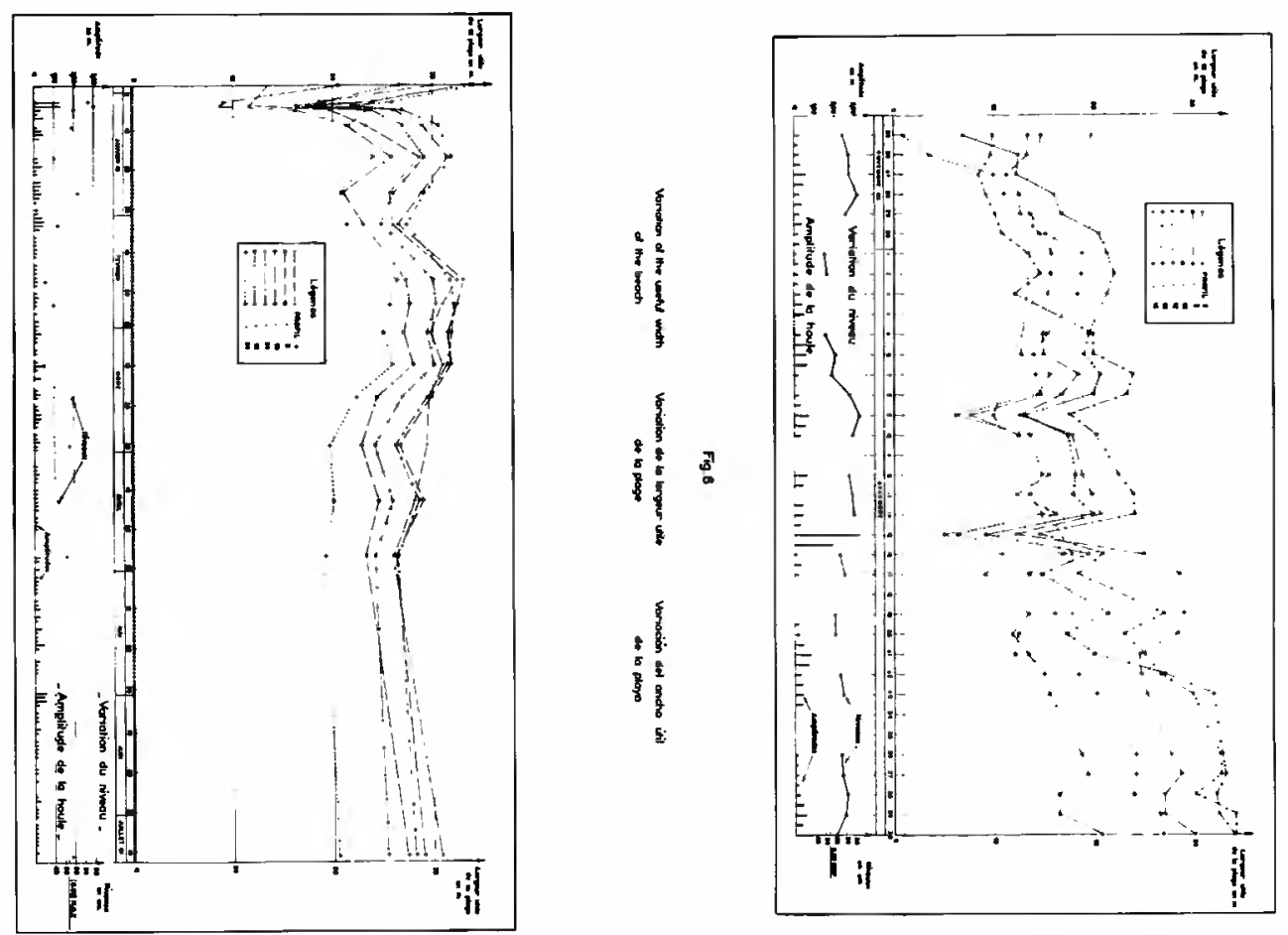

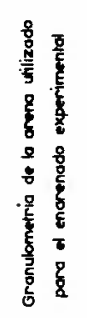

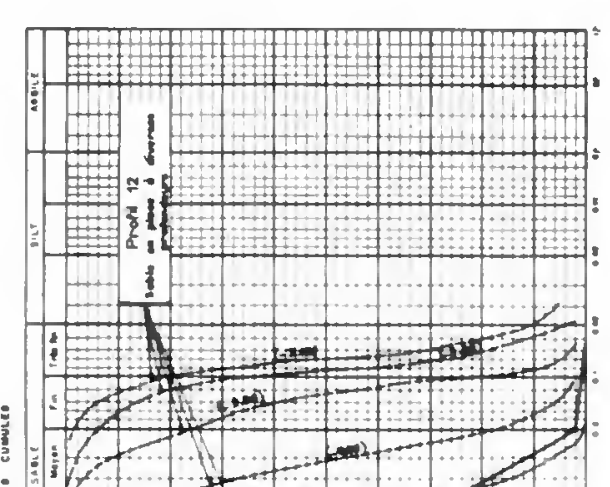

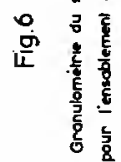
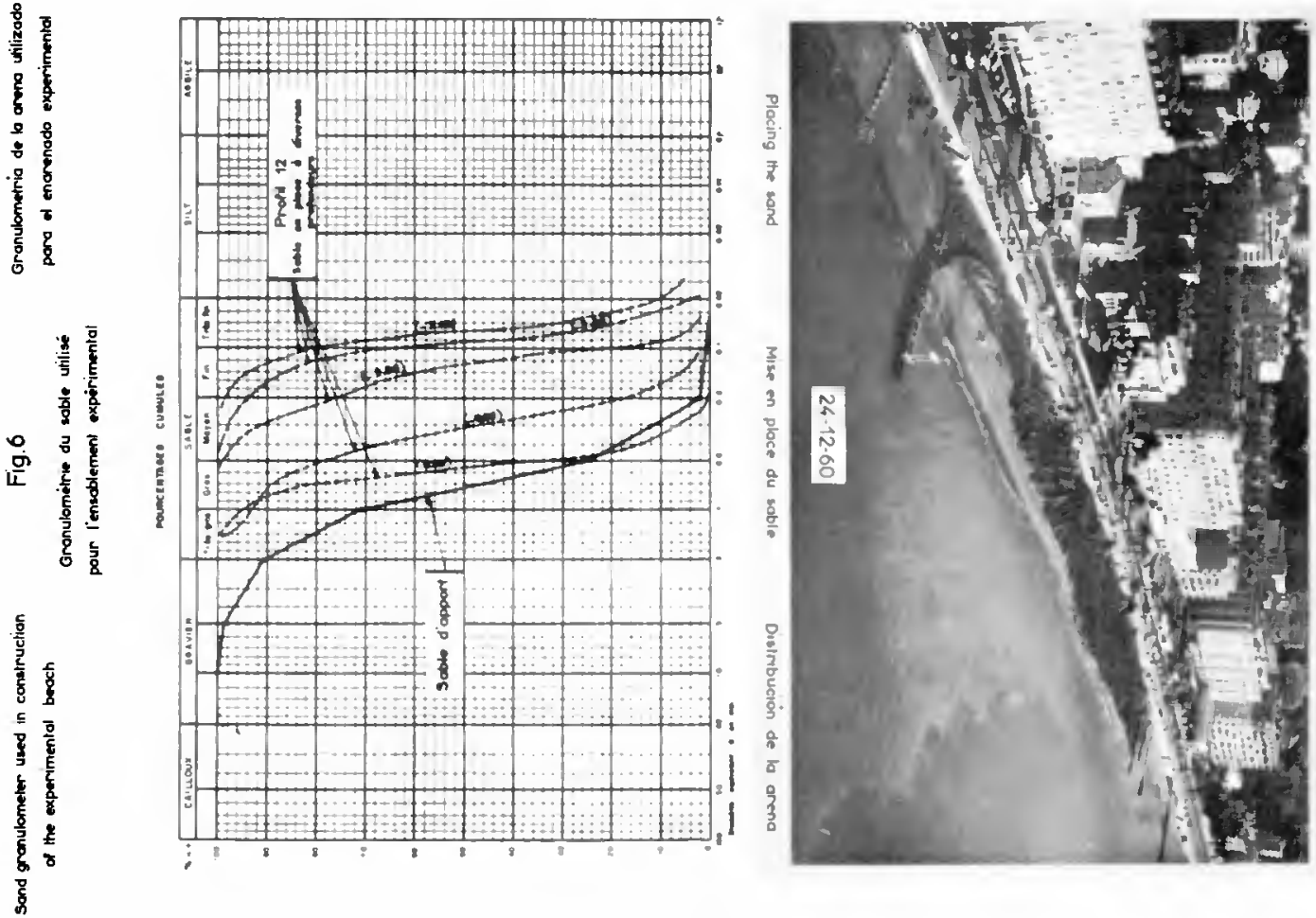


\section{ARTIFICIAL BEACH BUILDING ON THE CROISETTE WATERFRONT AT CANNES}

Sand was tipped directly at the head of the beach at speciallyprepared points along the Promenade de la Croisette, and afterwards levelled by bulldozer, so as to ensure proper spreading out.

It was lald in two successive operations, each layer measuring $50 \mathrm{cu}$. $\mathrm{m}$ per metre run. For the second operation the extension was taken $20 \mathrm{~m}$ beyond the former shore-line. Simultaneously with the dumping operations the eastern and western boundarıes and the experimental toe-mound were also placed in position.

No difficulties were experienced during dumping.

Fig. 7 gives an oblique aerlal view of the area during dumping operations.

\section{COASTAL DEVELOPMENT DURING AND AFTER DUMPING}

Various measurements and surveys were carried out at intervals during and after the beach bullding operations.

In particular :

Wave observations ;

Level varlation observations ;

Surveys of the useful width of the beach;

Survey of beach profiles.

F1g. 8 gives the results obtalned during two periods :

(1) $25 \mathrm{Nov}$. to $29 \mathrm{Dec} .1960$, when the average rate of dumping was $850 \mathrm{cu} \mathrm{m}$ per day.

(2) 2 Jan. to July 1961.

Also shown on the figures are:

Wave characteristıcs, e.g. amplitude, perıodıcıty ;

Levels observed ; and

Varlations in the useful width of the beach for six profiles.

This figure reveals the considerable increase in the width of the beach by means of a comparison between the starting (25.11.1960) and finishing (11.7.1961) ordinates.

It must be noted, however, that the increases are not completely valid and that the following two points must be borne in mind in interpreting the results :

a) A seasonal change in slope takes place between November 1960 and July, 1961. It is therefore difficult to compare increases for this period.

b) Since the very beginning of the dumping operations the western boundary of the area was leaking sand. It was in fact removed in the spring of 


\section{COASTAL ENGINEERING}

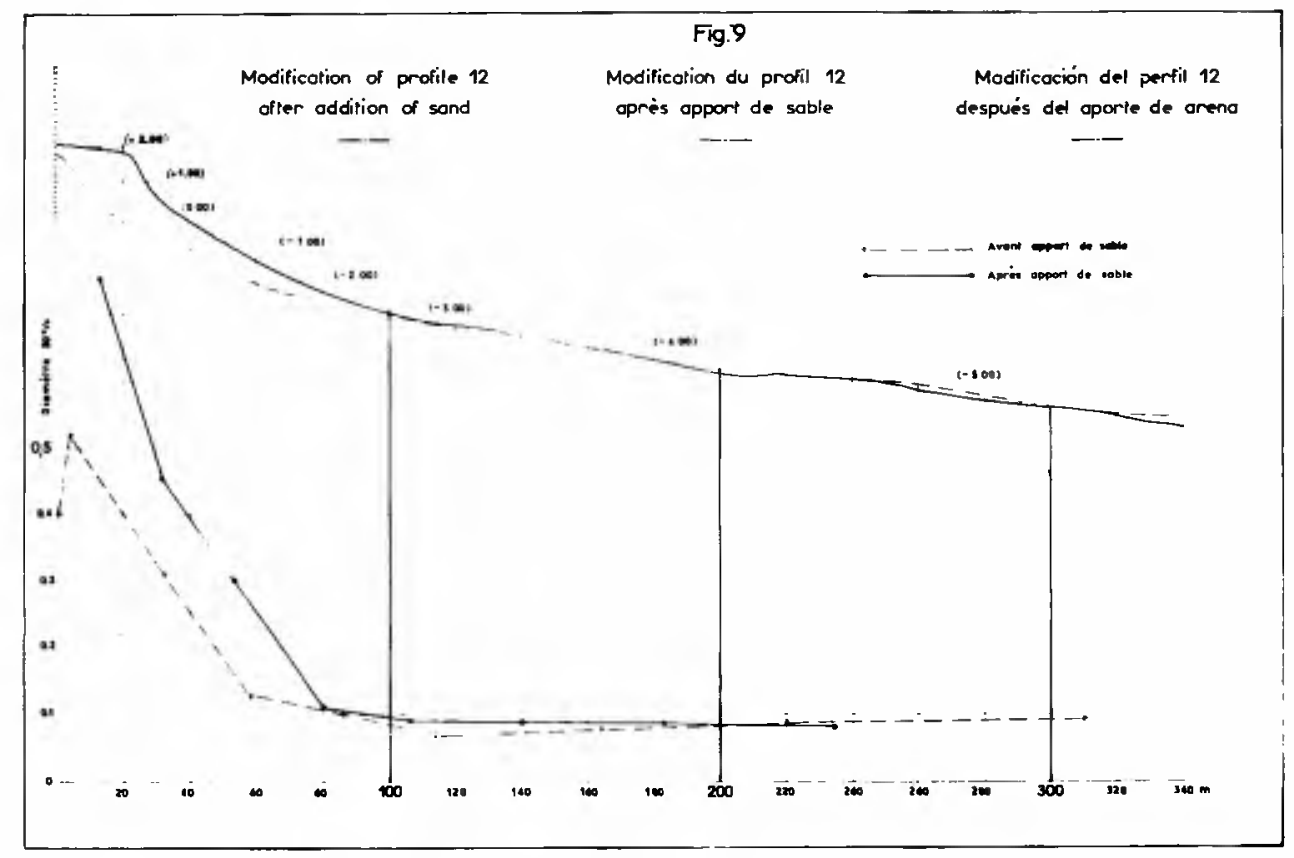

Fig. 10

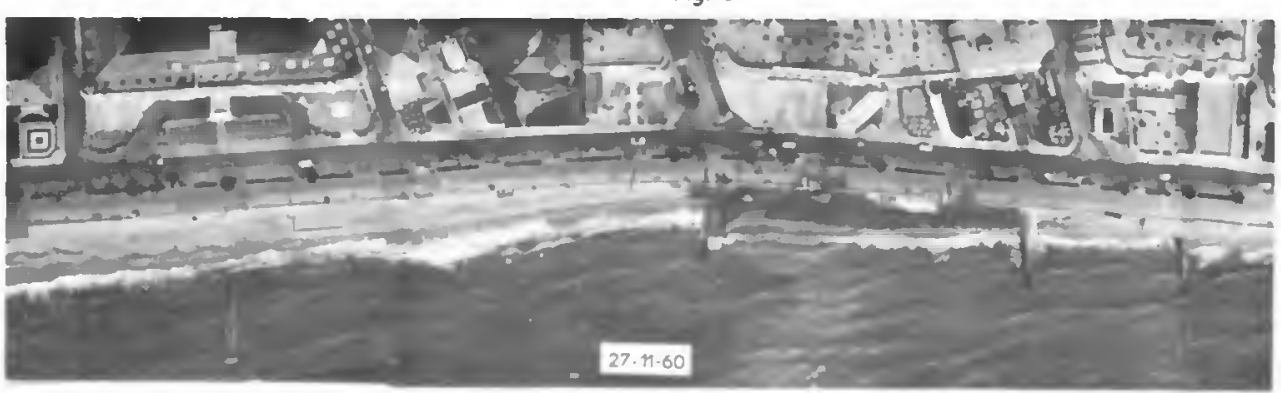

Aerial views

Vues aériennes

of the experimentol zone

de lo zone expérimentale

Vistos aéreas

de ta zono experimental

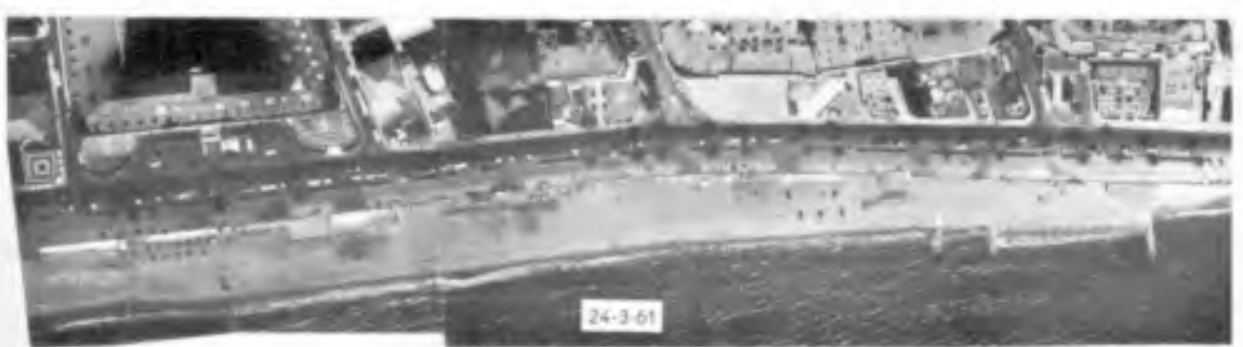




\section{ARTIFICIAL BEACH BUILDING ON THE CROISETTE WATERFRONT AT CANNES}

1961.

The movement of the sand was not simply lateral but also lengthways, a tendency which increased in the areas nearest the western boundary.

The eastern boundary being much more solid, movement of sand in this direction was very slight.

It is therefore safe to state that, owing to the leakage at the western limit, the June 1961 survey was no longer valid for the beach which had been built up by $88^{*}$ cu.m per metre run since this figure had been reduced by lateral losses.

These reservations having been made, the increase in effective width of the beach between November 1960 and July, 1961 may be given in the following table:

\begin{tabular}{|c|c|}
\hline Profile & $\begin{array}{c}\text { Increase in effective width between } \\
\text { November, } 1960 \text { and July, } 1961 .\end{array}$ \\
\hline $\begin{array}{c}6 \\
8 \\
10 \\
12 \\
14 \\
\text { at the dike near } \\
\text { to } 16\end{array}$ & $\begin{array}{l}11 \text { metres } \\
12 \text { " } \\
15 \text { " } \\
18 \text { " } \\
18 \text { " } \\
19 \text { " }\end{array}$ \\
\hline
\end{tabular}

Profiles were drawn on four occasions after completion of the experimental beach building project.

It is instructive to compare these with the profiles drawn before the start of the project. Owing to loss of sand towards the west, no useful purpose is served by study of the variations in depth of sand for a given profile over any considerable length of time, since the amount per metre run was not constant, even showing a decrease on the average.

In our opinion the two most interesting surveys were those of November 1960 and March, 1961 since the sideways spreading of the sand had not reached proportions large enough to produce inaccurate results. Furthermore this period includes the few days of heavy weather recorded during the winter of $1960-1961$. Fig. 9 gives proflle 12 in Nov. 1960 and March 1961. This figure also reveals that the extension was in the region of some $20 \mathrm{~m}$ and that the sand was not spreading seaward beyond a depth 


\section{COASTAL ENGINEERING}

of $-3 m$. The flgure also gives the graphs of the median diameter of samples from profile 12 before and after beach building. The points at which both profiles meet and the intersections of the grain size curves agree very well.

This diagram also demonstrates the irrelevance of the toe-mound.

The development of the coast was also recorded by vertical aerial photography.

Fig. 10 gives two such aerıal views.

CONCLUSIONS FROM THE EXPERIMENTAL BEACH BUILDING PROJECT

They are essentially as follows :

1) The addition of material in the experimental area 1100 cu $\mathrm{m}$ per metre run) led to an extension of approx. $20 \mathrm{~m}$.

2) The particle-size of the sand used was perfectly sultable for artificial beach building in the case of cannes. Particle-size was seen to be a basic princlple largely determining the success or failure of the project.

3) The toe-mound described above did not serve any useful purpose, since the sand did not reach 1 t.

Therefore it may be said that such a mound is not necessary for the complete and final extension of the croisette beach, provided that the materials used have the correct grading.

Summing up, it may be said that the experiments carried out on the site helped to conflrm the results of the preliminary studies.

From this point on the projected total bullding up of the beach could be faced with confidence, since the basic factors of a successful scheme had been established.

\section{FINAL EXTENSION OF THE CROISETTE BEACH}

\section{NATURE OF SAND USED}

The grading of the sand used was similar to those employed in the experimental section. 
ARTIFICIAL BEACH BUILDING ON THE CROISETTE WATERFRONT AT CANNES
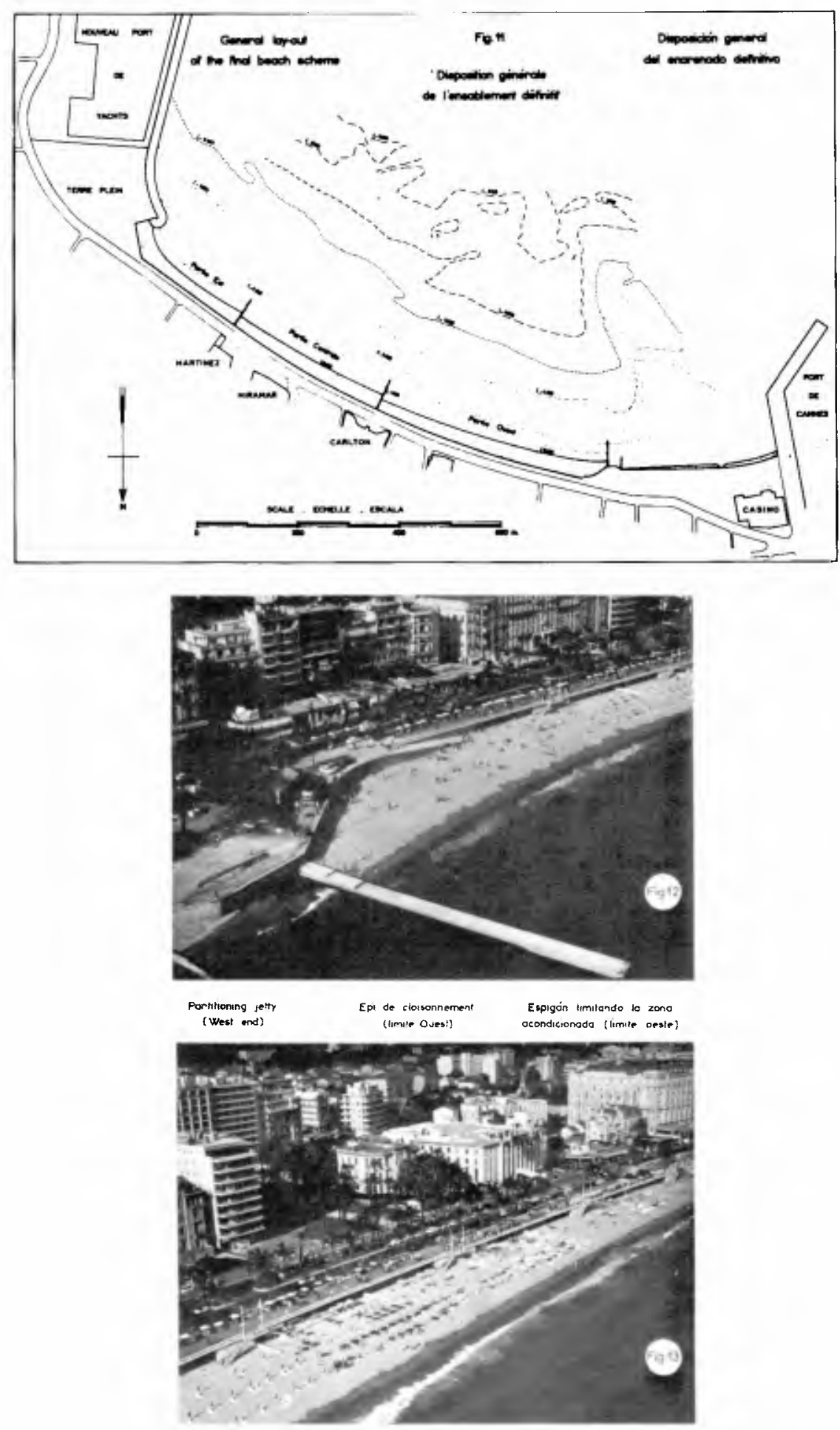

The beach opur improvement La playa despues det 


\section{COASTAL ENGINEERING}

\section{GENERAL LAY-OUT OF THE ARTIFICIAL BEACH}

Any plan or aerial photograph of the Crolsette beach before development immediately reveals that the shore-line is not parallel to the Promenade.

This is explained by the fact that the Promenade was built to follow the original shore-line existing before the construction of the Albert Edouard Jetty and the Casino foundation fill. Their construction modified the development of the beach to give it the form 1 t presented before the artificial extension works began.

It seems logical to presume that any such extension work undertaken without special precautions will lead to uniformity of outline, since all projections due to beach building will be smoothed away by wave action. Such an extension would be inflexible and unsulted to requirements at particular sections.

If it were desired to extend the narrowest part of the beach by, say, $30 \mathrm{~m}$, this would involve a generalised extension of the whole beach, whereas in the western area there is certainly no need for any such extension. The uneconomic nature of this method led us to envisage a partitioning system. If, in fact, the beach is divided into several sections, the extension of each one can be pursued independently of the others and the shore-line is stepped. Obviously the number of these partitions should be kept to a minimum, since the cost of the work should not exceed that of the sand economised. Aesthetıc considerations also prohibit an excess of these structures.

An adequate solution seemed to be three partitions and this was adopted, with the agreement of the Cannes Council Technical Department. The partitions take the form of jetties built of a double row of metal sheeting-piles (see fig. 11 ).

Rainwater has been led away to drain off inside the jetty.

Fig. 12 gives a general plan view of the final lay-out.

\section{TOTAL VOLUME OF SAND TO BE USED}

A break-down of the total volume (which it is estimated will be needed is as follows : 


\section{ARTIFICIAL BEACH BUILDING ON THE CROISET'TE WATERFRONT AT CANNES}

\begin{tabular}{|l|c|c|c|}
\hline Section & $\begin{array}{c}\text { Length } \\
\text { in metres }\end{array}$ & $\begin{array}{c}\text { Amount meas ured } \\
\text { in situ" } \\
\text { cu m }\end{array}$ & $\begin{array}{c}\text { Amount measured } \\
\text { in lorry loads } \\
\text { cu m }\end{array}$ \\
\hline West & 420 & 23,400 & $35,000^{*}$ \\
Centre & 320 & 24,600 & $37,000^{*}$ \\
East & 300 & 22,000 & $33,000^{*}$ \\
TOTAL & 1,040 & 70,000 & $105,000^{*}$ \\
\hline
\end{tabular}

\section{PRESENT STATE OF ARTIFICIAI, BEACH}

At the moment $60,000 \mathrm{cu} m$ of sand have been laid on the crolsette beach. The rest, some $105,000 \mathrm{cu} \mathrm{m}$ will have been laid by the end of the year. The partitions are wholly or partly finished.

The widening of the Promenade has been partly carried out in the form of a reinforced concrete structure overhanging the beach, the form of which shelters the bathing huts and places them out of sight from the Croisette. Sogreah was also responsible for the design of this structure, built on plers and therefore independent of all changes taking place in the beach.

The photograph in Flg. 13 glves some idea of this achlevement which has allowed Cannes to resolve two frequently incompatible problems:

The widening of a coast road

The widening of the beach separating this road from the sea. 